\title{
WD Repeat and FYVE Domain-Containing Protein 2
}

National Cancer Institute

\section{Source}

National Cancer Institute. WD Repeat and FYVE Domain-Containing Protein 2. NCI

Thesaurus. Code C122831.

WD repeat and FYVE domain-containing protein 2 (400 aa, $\sim 45 \mathrm{kDa}$ ) is encoded by the human WDFY2 gene. This protein may play a role in phospholipid or protein ligand binding. 